\title{
Pharmacological Potential of Fungal Endophytes Associated with Medicinal Plants: A Review
}

\author{
Bartholomew Saanu Adeleke (D) and Olubukola Oluranti Babalola *(D)
}

Citation: Adeleke, B.S.; Babalola O.O. Pharmacological Potential of Fungal Endophytes Associated with Medicinal Plants: A Review. J. Fungi 2021, 7, 147. https://doi.org/ 10.3390/jof7020147

Academic Editor: Gary A. Strobel

Received: 10 January 2021

Accepted: 2 February 2021

Published: 17 February 2021

Publisher's Note: MDPI stays neutral with regard to jurisdictional claims in published maps and institutional affiliations.

Copyright: (c) 2021 by the authors. Licensee MDPI, Basel, Switzerland. This article is an open access article distributed under the terms and conditions of the Creative Commons Attribution (CC BY) license (https:/ / creativecommons.org/licenses/by/ $4.0 /)$.
Food Security and Safety Niche Area, Faculty of Natural and Agricultural Sciences, North-West University, Private Bag X2046, Mmabatho 2735, South Africa

* Correspondence: olubukola.babalola@nwu.ac.za; Tel.: +27-(0)18-389-2568
Abstract: Endophytic microbes are microorganisms that colonize the intracellular spaces within the plant tissues without exerting any adverse or pathological effects. Currently, the world population is facing devastating chronic diseases that affect humans. The resistance of pathogens to commercial antibiotics is increasing, thus limiting the therapeutic potential and effectiveness of antibiotics. Consequently, the need to search for novel, affordable and nontoxic natural bioactive compounds from endophytic fungi in developing new drugs with multifunction mechanisms to meet human needs is essential. Fungal endophytes produce invaluable bioactive metabolic compounds beneficial to humans with antimicrobial, anticancer, antidiabetic, anti-inflammatory, antitumor properties, etc. Some of these bioactive compounds include pestacin, taxol, camptothecin, ergoflavin, podophyllotoxin, benzopyran, isopestacin, phloroglucinol, tetrahydroxy-1-methylxanthone, salidroside, borneol, dibenzofurane, methyl peniphenone, lipopeptide, peniphenone etc. Despite the aforementioned importance of endophytic fungal metabolites, less information is available on their exploration and pharmacological importance. Therefore, in this review, we shall elucidate the fungal bioactive metabolites from medicinal plants and their pharmacological potential.

Keywords: antibiotics; antimicrobial; fungal metabolites; medicinal plants; pharmacology

\section{Introduction}

Medicinal plants harbor diverse populations of microbial domains. Their interdependence in the synthesis of bioactive compounds as a therapy to confront the emergence of new drug-resistant pathogens has increased the quest for an alternative to chemosynthetic drugs for treating human diseases [1-3]. Despite the tiny nature of fungi, for example, Penicillium notatum has been used as an invaluable source of novel metabolite compounds and broad-spectrum antibiotics, as credited to Alexander Fleming in the discovery of penicillin [4]. Since then, this antibiotic has continued to dominate the market and has also awakened the consciousness of scientists in the search for bioactive metabolites from fungi inhabiting the soil (rhizosphere) or plant endosphere [5,6].

The endosphere depicts the inner part of the plant with different microorganisms inhabiting the zone, completing their life span without exercising pathological consequences on the host plants $[7,8]$. Fossil records in the study of plant microbial ecology have shown the prehistorical interaction of fungal endophytes with plants; most fungal endophytes interacting with plants originated when higher plants were first seen on Earth, as documented in [9]. Fungal endophytes are symbiotically associated with their host plants; their mutual interdependence enabled them to confer beneficial effects and support each other [10]. Plants secrete exudates that supply nutrients to the endomycorrhiza in the rhizosphere and other endophytes infiltrating the root tissues; in return, the fungal endophytes chiefly support their host plants to survive under different environmental stresses by the secretion of stress-adaptor metabolites [11-13].

To date, reports have shown that $7 \%$ of 1.5 million fungal species have been identified; although recent findings using next-generation sequencing have revealed that between 3.5 
and 5.1 million fungal species exist on earth [14], as opposed to earlier reports in 2017 by Hawksworth and Lücking [15] that about 2.2 to 3.1 million fungal species exist worldwide. Fungal endophytes are thus dominating the ecosystem and can be promising as a source of different bioactive compounds.

It is expected that despite the multidisciplinary research approached in the study of endophytes and its various bioactive compounds, the discipline is still in its infancy, and little success has been recorded in the synthesis of endophytic fungal bioactive compounds for commercial purposes. Therefore, the biotechnological application of fungal endophytes in agriculture and industries in the derivation of salient natural plant products became necessary. The discovery of new metabolic compounds from medicinal plants and associated fungi has been documented in several research findings [16-18]. Currently, Pelargonium sidoides has been recognized as the most invaluable medicinal plant used traditionally in primary health care in South Africa and research on the antibacterial properties of the diverse endophytic fungal extract from Pelargonium sidoides DC has been documented [17]. The resulting potentials of this plant and other medicinal plants in the synthesis of bioactive compounds have been documented [19]. Likewise considered, but less studied, are the bioactive compounds that are synthesized by the endophytic fungi. Hence, critical elucidation on endophyte ecology, bioactive components, and the biotransformation of fermentable substrates in culturing and biomass production is paramount. Therefore, in this review, the various bioactive compounds from endophytic fungi associated with medicinal plants and their pharmacological importance shall be discussed.

\section{Bioactive Compounds from Medicinal Plants}

In nature, different medicinal plants are found in the ecosystem as a source of curative substances for various diseases, and are employed in modern therapeutics as an alternative to chemical drugs [20]. In developing countries, approximately $80 \%$ of people rely on herbal medicines as their sole primary healthcare. Studies have revealed that about $51 \%$ of new drugs developed between 1981 and 2014 were naturally synthesized from plants, as they have been experimentally tested against some infectious diseases and for treating cancer [21,22]. Globally, the trend of medicinal plant usage is increasing based on the high demand for herbal drugs and pharmaceuticals. However, the cultivation of medicinal plants is faced with many challenges arising from overharvesting without replanting, ecological distortion, natural anthropogenic activities, and the destruction of habitat by pest infestation, thus reducing the plant population and its exploration for medicinal use [16].

In reality, the exploitation of plant bioactive products can be infeasible due to the small amount of product accumulation in plants, long maturation time, and difficulty in the recovery of plant metabolites. Nevertheless, to maximally explore bioactive compounds from plants, it is imperative to devise an alternative means of scaling up the cultivation of medicinal plants to meet demand through the total chemical synthesis, heterologous production, tissue culture, semisynthesis, microbial synthesis or plant synthesized natural products or exploitation of endophytic microbes (fungi) in the synthesis of the corresponding bioactive compounds as their hosts [23]. Research has established that approximately $18 \%$ of plant-derived metabolites can as well be derived from its associated fungi [24]. For example, similar bioactive compound, Taxol has been derived from a medicinal plant, Taxus, and its associated endophytic fungi Taxomyces andreanae [25]. Hence, the Taxol from T. andreanae can preferably stand promising over its host plant due to ease of exploration by fermentation and production [26]. Furthermore, studies in the literature on some medicinal plants and endophytes in the synthesis of bioactive compounds with more emphasis on plant species and organs as sources of bioactive metabolites have been reported [27,28].

\section{Pharmacological Effects of Bioactive Compounds of Fungal Metabolites}

Endophytic fungi potentially produce novel bioactive compounds. Suitable media, growth parameters and nutrient limitation should be explored to gain insight into fungal 
metabolism to discover novel pharmaceutical products [29]. Hence, the pharmacological properties of major bioactive compounds synthesized from endophytic fungi and significant effects are represented in Table 1 and further highlighted below:

Table 1. The effects of bioactive compounds of fungal endophytes associated with medicinal plants.

\begin{tabular}{|c|c|c|c|}
\hline Medicinal Plant & Endophytic Fungi & Bioactive Compounds/Effects & References \\
\hline $\begin{array}{c}\text { Taxus brevifolia } \\
\text { Aegle marmelos } \\
\text { Plectranthus amboinicus, } \\
\text { Wollemia nobilis } \\
\text { Ginkgo biloba } \\
\text { Taxus media } \\
\text { Taxodium distichum } \\
\text { Terminalia arjuna } \\
\text { Citrus medica }\end{array}$ & $\begin{array}{c}\text { Taxomyces andreanae } \\
\text { Bartalalinia robillardoide } \\
\text { Pestalotiopsis microspore } \\
\text { P. guepinii } \\
\text { P. microspore } \\
\text { P. terminaline } \\
\text { Cladosporium cladosporio } \\
\text { Phyllosticta citricarpa }\end{array}$ & $\begin{array}{c}\text { Anticancer/Antitumor } \\
\text { Paclitaxel }\end{array}$ & \multirow{7}{*}[30,31]{} \\
\hline $\begin{array}{l}\text { Taxodium distichum } \\
\text { Rhizophora annamalayana } \\
\text { Taxus baccata }\end{array}$ & $\begin{array}{c}\text { Alternaria alternata, } \\
\text { Aspergillus fumigatus } \\
\text { Pestalotiopsis terminaliae, Wollemia nobilis, } \\
\text { Baralinia robillardoides, Taxodium distichum, } \\
\text { Phyllosticta spinarum, Botrydiplodia theobromae }\end{array}$ & Taxol & \\
\hline $\begin{array}{c}\text { Taxus baccata } \\
\text { Camptotheca acuminate } \\
\text { Apodytes dimidiate }\end{array}$ & $\begin{array}{c}\text { Fusarium oxysporum, } \\
\text { Fusarium redolens, Fusarium solani, } \\
\text { Trichoderma atroviride }\end{array}$ & Camptothecin & \\
\hline $\begin{array}{c}\text { Sinopodophyllum hexandrum } \\
\text { Diphylleia sinensis } \\
\text { Adenophora axilliflora }\end{array}$ & $\begin{array}{c}\text { Fusarium solani } \\
\text { Penicillium implicatum } \\
\text { Mucor fragilis, Phialocephala fortinii }\end{array}$ & $\begin{array}{l}\text { Podophyllotoxin } \\
\text { Chaetominine }\end{array}$ & \\
\hline $\begin{array}{l}\text { Melia azedarach } \\
\text { T. taxifolia } \\
\text { D. cejpii }\end{array}$ & $\begin{array}{l}\text { Penicilium brasilianum } \\
\text { Pestalotiopsis microspore } \\
\text { Dichotomomyces albus }\end{array}$ & $\begin{array}{l}\text { Phenylpropanoids } \\
\text { Torreyanic acid } \\
\text { Xanthocillin X }\end{array}$ & \\
\hline $\begin{array}{l}\text { Cardiospermum helicacabum } \\
\text { Nothapodyte foetida } \\
\text { Juniperus communis } \\
\text { Juniperus recurva } \\
\text { Podophyllum hexandrum } \\
\text { Dysosma veitchii Podophyllum } \\
\text { peltatum } \\
\text { Sinopodophyllum hexandrum }\end{array}$ & $\begin{array}{l}\text { Pestalotiopsis pauciseta } \\
\text { Entrophospora infrequent } \\
\text { Aspergillus fumigatus } \\
\text { Fusarium oxysporum } \\
\text { Trametes hirsute } \\
\text { Penicillium implicatum } \\
\text { Phialocephala fortinii } \\
\text { Alternaria neesex }\end{array}$ & $\begin{array}{l}\text { Camptothecin } \\
\text { Podophyllotoxin }\end{array}$ & \\
\hline $\begin{array}{l}\text { Catharanthus roseus } \\
\text { Tripterygium wilfordii } \\
\text { Roystonea regia } \\
\text { Cyndon dactlon }\end{array}$ & $\begin{array}{l}\text { Fusarium oxysporum } \\
\text { Rhinocladiella spp. } \\
\text { Pestalotiopsis photiniae } \\
\text { Aspergillus niger IFB-E003 }\end{array}$ & $\begin{array}{l}\text { Vincristine } \\
\text { Cytochalasins } \\
\text { Photinides } \\
\text { Rubrofusarin B }\end{array}$ & \\
\hline $\begin{array}{c}\text { Urospernum picroide } \\
\text { Garcinia dulcis } \\
\text { Saurauia scaberrinae } \\
\text { Torreya taxifolia } \\
\text { Kennedia nigriscans } \\
\text { Crytosporiopsis cf quercina }\end{array}$ & $\begin{array}{c}\text { Ampelomyces spp. } \\
\text { Phomopsis spp. PSU-D15 } \\
\text { Phoma spp. } \\
\text { Pestalotiopsis microspora } \\
\text { Streptomyces NRRL } 30562 \\
\text { Cryptosporiopsis spp. }\end{array}$ & $\begin{array}{c}\text { Antimicrobial } \\
\text { 3-0 methylalaternin, altersolanol A } \\
\text { Phomoenamides } \\
\text { Phomodione } \\
\text { Ambuic acid } \\
\text { Mumubicin } \\
\text { Cryptocandin }\end{array}$ & [32] \\
\hline Sabina recurve & $\begin{array}{l}\text { Fusarium oxysporum } \\
\text { Penicillium chrysogenum }\end{array}$ & $\begin{array}{c}\text { Antiviral } \\
\text { Cyclosporine } \\
\text { Xanthoviridicatins }\end{array}$ & [30] \\
\hline $\begin{array}{c}\text { Smallanthus sonchifolius } \\
\text { Viguiera arenaria }\end{array}$ & $\begin{array}{l}\text { Curvularia spp. } \\
\text { Phomopsis spp. }\end{array}$ & $\begin{array}{c}\text { Antimalaria/antiparasite } \\
\text { Stemphyperylenol } \\
\text { 3,4-dimethyl-2-(40-hydroxy-30,50- } \\
\text { dimethoxyphenyl)-5-methoxy- } \\
\text { tetrahydrofuran }\end{array}$ & [28] \\
\hline Citrus limon & Penicillium digitatum, P. citrinum & $\begin{array}{c}\text { Antifungal } \\
\text { Tryptoquialanine A, Tryptoquialanine C, } \\
\text { 15-dimethyl-2-epi-fumiquinazoline A, } \\
\text { deoxytryptoquialanone, Citrinadin A, } \\
\text { Deoxycitrinadin A, Chrysogenamide A }\end{array}$ & {$[33,34]$} \\
\hline
\end{tabular}


Table 1. Cont.

\begin{tabular}{|c|c|c|c|}
\hline Medicinal Plant & Endophytic Fungi & Bioactive Compounds/Effects & References \\
\hline Senecio kleinii & Phoma sp. & $\begin{array}{l}\text { 8,9-dihydro-3,5,7-trihydroxy-1,8,8,9- } \\
\text { tetramethyl-5-(2-oxopropyl)-4H- } \\
\text { phenaleno[1,2-b]furan- } 4,6(5 \mathrm{H}) \text {-dione, } \\
\text { atrovenetinone, sclerodione }\end{array}$ & [35] \\
\hline $\begin{array}{c}\text { Acacia nilotica } \\
\text { Adhatoda beddomei, Ficus religiosa, } \\
\text { Paeonia delavayi, } \\
\text { Salvadora oleoides Decne } \\
\text { Sonneratia ovata }\end{array}$ & $\begin{array}{c}\text { Aspergillus awamori } \\
\text { Syncephalastrum spp. } \\
\text { Dendryphion nanum, Phomopsis spp. } \\
\text { Aspergillus spp Phoma spp. } \\
\text { Nectria spp. }\end{array}$ & $\begin{array}{c}\text { Antidiabetic } \\
\text { Peptide lectin (N-acetylgalactosamine, } \\
64 \text { kDa) } \\
\text { Naphthoquinones (O-phenethylherbarin), } \\
\text { herbarin and herbaridine, } \\
\text { phomopoxides A-G, } \\
\text { 2,6-di-tert-butyl-p-cresol, } \\
\text { phenol-2,6-bis[1,1-dimethylethyl]-4-methyl } \\
\text { Citreoisocoumarinol, citreoisocoumarin, and } \\
\text { macrocarpon C }\end{array}$ & \\
\hline Solanum xanthocarpum & Aspergillus terreus, A. sclerotiorum, A. terreus & $\begin{array}{l}\text { Antioxidants } \\
\text { Lovastatin }\end{array}$ & [36] \\
\hline $\begin{array}{c}\text { Magnifera casturi, } \\
\text { Cestrum nocturnum, Nerium oleander, } \\
\text { Saposhnikoviadivaricata, Acalypha } \\
\text { indica, } \\
\text { Azadirachta indica, Catharanthus } \\
\text { roseus, Pediomelum cuspidatum, } \\
\text { Artemisia capillaris, Catharanthus } \\
\text { roseus } \\
\text { Caralluma acutangula, Rhazya stricta, } \\
\text { and Moringa peregrina } \\
\text { Eugenia jambolana, Fritillaria } \\
\text { unibracteata, Gymnema sylvestre, } \\
\text { Kandis gajah }\end{array}$ & $\begin{array}{l}\text { Aspergillusminisclerotigenes, Asper. oryzae, } \\
\text { Asper. wentii, Rhodiola crenulata, Rhod. } \\
\text { angusta, Rhod. sachalinensis, Chaetomium sp., } \\
\text { Diaporthe phaseolorum, Colletotrichum kohawae, } \\
\text { Phomopsis phylanthicolla, Xylaria acuta, } \\
\text { Alternaria alternata, Bipolaris sorokiniana, and } \\
\text { Cladosporium sphaerosperumum } \\
\text { Aspergillus niger, Aspergillus peyronelii, } \\
\text { Aspergillus sp., and Chaetomium globosum, } \\
\text { Fusarium tricinctum, Clonostachys rosea, } \\
\text { Gymnema sylvestre, } \\
\text { Chrysonilia sitophila } \\
\text { Alternaria alternata }\end{array}$ & $\begin{array}{c}\text { Phenolic acids (Chlorogenic acid } \\
\text { (5-O-caffeoylquinic acid), } \\
\text { Di-O-caffeoylquinic acids } \\
\text { Flavonoids (Quercetin 3-rutinoside) (rutin), } \\
\text { Quercetin 3-rhamnoside, (quercitrin) } \\
\text { Quinones (Anthraquione glycoside) } \\
\text { Rehein, emodin } \\
\text { Volatile compounds (Artemisin) } \\
\text { Aliphatic compounds } \\
\text { Hexadecanoic acid, methyl ester; } \\
\text { 9-Hexadecenoic acid, methyl ester; 9,12 } \\
\text { Octadecadienoic acid, methyl ester; } \\
\text { 11,14,17-Eicosatrienoic acid, methyl ester } \\
\text { DPPH (2,2-diphenyl-1-picrylhydrazyl) } \\
\text { 3,5-dihydroxy-2,5-dimethyltrideca } \\
\text { 2,9,11-triene- 4,8-dione } \\
\text { Chrysin }\end{array}$ & {$[34,37-39]$} \\
\hline Polygonum cuspidatum & Streptomyces spp. & $\begin{array}{c}\text { 3-methyl-1-butanol, 4-methyl-1-pentanol, } \\
\text { 1-nonanal, } \\
\text { 6-methyl-2-oxiranyl-hept-5-en-2-ol, } \\
\text { 2,6,11,15-tetramethylhexadecane, } \\
\text { 2,6-dimethylocta-2, 7-dien-6-ol, } \\
\text { 2,4-di-tert-butylphenol, glacial acetic acid, } \\
\text { linoleic acid, 4-methylvaleric acid, } \\
\text { 4-hexenoic acid, dehydroacetic acid, } \\
\text { heptanedioic acid, 2-methyl butyric acid, } \\
\text { and 1-p-menthen-8-ol }\end{array}$ & [40] \\
\hline
\end{tabular}

\subsection{Antifungal}

Recent research findings into fungal endophytes as a source of antimicrobial compounds have provided alternative means in overcoming drug resistance by pathogens, the inefficiency of antibiotic activity against bacterial species, and a limited amount of antimicrobial production [41]. The antibacterial, antifungal, antiprotozoan, and antiviral activities of antimicrobial compounds synthesized by endophytic fungi have helped prevent various disease conditions affecting living organisms [17,42].

Examples of antimicrobial compounds produced by endophytic fungi include clavatol, chaetomugilin $\mathrm{D}$, guignardic acid, colletotric acid, viridicatol, 7-amino-4-methylcoumarin, altersolanol A, 2-hydroxyl-6 methyl benzoic acid, enfumafungin, xylarenone B, jesterone, pestacin, hydroxy-jesterone, rutin, fusapyridon $\mathrm{A}$, hypericin, phomopsin $\mathrm{A}$, isopestacin, xylarenic acid, fusaripeptide $\mathrm{A}$, xylarenone $\mathrm{A}$, javanicin, Z-roquefortine $\mathrm{C}$, penitrem $\mathrm{A}$, penijanthine $\mathrm{A}$, fusarithioamide $\mathrm{A}$, pestalone, cryptocandin cryptocin, ecomycins, pseudomycins, pestaloside and pestalopyrone [43]. The isolation of Streptomyces spp. TQR12-4 from Elite Citrus nobilis fruit with broad-spectrum antimicrobial activity against fungi 
pathogens Colletotrichum truncatum, Geotrichum candidum, F. oxysporum, and F. udum has been reported [44].

Some bioactive compounds such as triterpenoids, sesquiterpenes, and diterpenoids produced from endophytic fungi account for their antimicrobial activity against some fungal and bacterial pathogens [45]. In Chinese herbal medicines, diverse fungal endophyte communities isolated from the roots of Paris polyphylla have traditionally been employed. Similarly, the colletotric acid $\left(\mathrm{C}_{28} \mathrm{H}_{28} \mathrm{O}_{10}\right)$ antimicrobial substance produced by the fungal endophyte Colletotrichum gloesporoides from the Chinese medicinal plant Artemisis mongolica has potentially displayed antimicrobial properties [46].

Antimicrobial compounds are relatively low in molecular weight, and even at a low concentration $(0.5-8.0 \mathrm{mg} / \mathrm{mL})$, they exhibit high activity against pathogenic microorganisms [47]. Endophytes undergo indirect mechanisms by secreting biocides inhibitory to plant pathogens [48]. This mechanism is believed to be powered by the bioactive metabolites produced by the endophytes. Different antimicrobial compounds such as peptides, phenols, terpenoids, steroids, alkaloids, flavonoids, and quinine, produced by endophytes, have been reported [49].

Based on human perception, antimicrobial compounds can be employed in diverse ways not only as drugs but also in food processing and preservation. Some antimicrobials exhibited lethal effects on pathogenic or spoilage microorganisms causing food poisoning or intoxication. The production of antimicrobial compounds from endophytic fungus Armillaria mellea with high bioactivity against Gram-positive bacterial and fungal pathogens has been reported [50]. Furthermore, some endophytic fungi in the genus Xylaria produce certain bioactive compounds with antifungal activity. Examples of such compounds include sordaricin, 1, 8-dihydroxynaphthol 1-O-a-glucopyranoside, mellisol, and multiplolides $\mathrm{A}$ and $\mathrm{B}$. Sordarcin and multiplolides $\mathrm{A}$ and $\mathrm{B}$, which display antifungal activity against Candida albicans while 1, 8-dihydroxynaphthol 1-O-a-glucopyranoside and mellisol with antifungal activity against herpes simplex virus-type 1 are also known. The Xylaria spp. YX-28 isolated from Gingko biloba produced bioactive compound 7-amino-4-methylcoumarin [51]. These bioactive compounds exhibit broad-spectrum activity that causes the inhibition of the growth of spoilage or pathogenic microbes associated with foods, thus suggesting their use as a natural preservative in foods [51]. The common food microflora that causes food spoilage include Staphylococcus aureus, Salmonella typhimurium, S. typhi, S. enteritidis, Shigella dysenteriae, Yersinia spp., Penicillium expansum, Candida albicans, Aeromonas hydrophila, Vibrio parahaemolyticus, V. anguillarum, Aspergillus niger, and A. hydrophila [52].

Additionally, the Xylaria spp. F0010 isolated from Abies holophylla has been characterized as producing griseofulvin with the chemical formula $\left(\mathrm{C}_{17} \mathrm{H}_{17} \mathrm{C}_{1} \mathrm{O}_{6}\right)$, a spirobenzofuran antibiotic [53]. Griseofulvin has been employed for treating mycotic diseases in animals as well as human-related conditions. The in vitro and in vivo screening of genus Xylaria in the production of griseofulvin with microbicidal actions on plant pathogens as an effective biological agents in the control of fungal diseases affecting various food crops has been documented [54].

The extraction of Cytosporone B and C and Chaetomugilin A and D from the endophytic fungi Chaetomimum globosum and Phomopsis species inhabiting Ginkgo biloba with antifungal actions on Candida albicans and Fusarium oxysporum has been reported [51]. The antibacterial activities of a bioactive metabolite compound secreted by fungal endophytes in the genera Chaetomium, Curvularia, Fusarium, and Aspergillus cause inhibition growth of many bacteria [55]. The antibacterial activity (bactericidal and bacteriostatic) of Xanthomonas compestris and X. oryzae and antifungal activity of Magnaporthe oryzae, Fusarium oxysporum and Rhizoctonia solani isolated from Phoma species have been reported [56].

Furthermore, the antimicrobial, herbicidal and algicidal agents from chlorinated metabolites cryptosporiopsin (+) and mycorrhizin A (-) from endophytic Pezicula strains have been documented [57]. Similarly, the antifungal activity of chlorinated benzophenone derivatives such as Pestalachlorides $A$ with the chemical formula $\left(\mathrm{C}_{21} \mathrm{H}_{21} \mathrm{C}_{12} \mathrm{NO}_{5}\right)$ and Pestalachlorides $B$ with the chemical formula $\left(\mathrm{C}_{20} \mathrm{H}_{18} \mathrm{C}_{12} \mathrm{O}_{5}\right)$ extracted from the plant endo- 
phytic fungus Pestalotiopsis adusta against fungal plant pathogens Verticillium albo-atrum, Gibberella zeae, and Fusarium culmorum have been documented [58]. Kamana, et al. [59] demonstrated the antimicrobial activity of hypericin $\left(\mathrm{C}_{30} \mathrm{H}_{16} \mathrm{O}_{8}\right)$ and emodin $\left(\mathrm{C}_{15} \mathrm{H}_{10} \mathrm{O}_{5}\right)$ from fungal endophytes isolated from medicinal plants against Klebsiella pneumoniae ssp. ozaenae, Pseudomonas aeruginosa, Staphylococcus aureus, Salmonella enterica, Escherichia coli, Candida albicans and Aspergillus niger.

Metabolic compounds such as 2,6-dihydroxy-2-methyl-7-(prop-1E-enyl)-1-benzofuran$3(2 \mathrm{H})$-one, munumbicin $\mathrm{A}, \mathrm{B}, \mathrm{C}$, and $\mathrm{D}$, altersolanol A, 3-O-methylalaternin, phomoenamide, ambuic acid, fumigaclavine $C$, asperfumoid, fumitremorgin $C$, physcion, helvolic acid, isopestacin, ergosterol peroxide, phomodione, and pestalotheol $\mathrm{C}$ produced by endophytic fungi Aspergillus fumigatus CY018, Pestalotiopsis theae by various plants exhibiting potent inhibition against some fungal and viral pathogens such as Candida albicans are known [60].

\subsection{Anticancer}

Despite the clinical research in developing new chemotherapies, cancer remains a major disease with a high mortality rate in humans. Cancer is a human disease that causes abnormal cell growth at the point of infection that can later invade or spread to other parts of the body. In 2020, the American Cancer Society (ACS) reported 1.8 million incidences and 606,520 cancer deaths, while in 2018, World Health Organization (WHO) reported 18.1 million cancer incidence with total 9.6 million deaths. To this backdrop, a decline in the cancer incidence and mortality rates observed could be due to the intake of a balanced diet, early diagnosis and treatment. Many anticancer drugs have been synthesized and used with success. The effectiveness of anticancer drugs depends on the type, location and route of injection. The prolonged use of anticancer agents has threatened human life with numerous side effects, which include sores in the mouth and mucosa lining, hair loss, cardiac stress, nausea, bone marrow toxicity and vomiting. From this premise, evaluating the potential of some plant-associated fungi is fundamental and promising as a source of anticancer agents, but little is known about fungal anticancer agents. For example, the discovery of anticancer drug (Taxol) from an endophytic fungus, Taxomyces andreanae associated with the bark of Taxus brevifolia has been demonstrated.

As shown above, in Table 1, some examples of novel bioactive compounds from medicinal plants and endophytic fungi are listed. These compounds can be explored in the synthesis of natural products. Based on the multifunctional therapy of Taxol from T. andreanae that impedes the proliferation, growth and spread of cancer cells, the Food and Drug Administration (FDA) has considered it safe and approved it for treating cancer. Furthermore, studies have revealed the anticancer properties of phenylpropanoid's amide produced from Penicillium brasilianum associated with the root bark of Melia azedarach [61]. Similarly, podophyllotoxin from Phialocephala fortini, Juniperus communis, and Trametes hirsute inhabiting the endosphere of Podophyllum peltatum and Juniperus recurve are known as sources of anticancer agents, respectively [62].

Various fungal metabolites have been produced in vivo, via in vitro assays or via fermentation technology. The screening of natural bioactive compounds from endophytic fungi has advanced their pharmacological bioprospecting in discovering new drugs. The ability of endophytic fungi to grow in the fermentation medium based on their cytotoxic actions via the secretion of specific novel bioactive metabolites has revealed their potential as an effective anticancer agent $[63,64]$. The potent cytotoxicity of natural-products derived from medicinal plants and their exploration is faced with a lot of challenges. Some of these challenges include low concentrations of derivable metabolites from fungal endophytes. For example, a low concentration, $0.01-0.03 \%$ of paclitaxel from the phloem of Taxus has been documented [65]. Furthermore, the reisolation of desired bioactive compounds from medicinal plants, geographical location, seasonal and variations in environmental conditions have been identified as serious challenges. Supply issues may also be a severe concern if a source medicinal plant is endangered or has been collected in a politically 
quixotic part of the world. Other problems include the destruction of essential plant crops over time since the repeated collection of plant tissues without replenishment can cause plant species to become endangered and lost after some years.

\subsection{Antimicrobial Compounds Antitubercular}

Tuberculosis (TB) is a respiratory disease that affects the human lungs, caused by a bacterium, Mycobacterium tuberculosis. In the world today, the prevalence of TB is commonly high among immunocompromised individuals [66]. Symptoms include fever, fatigue, weight loss, cough, night sweats, etc. According to the World Health Organization (WHO) in 2018, 1.1 million of 2.3 million new TB cases recorded affected children between ages 0-14, and 230,000 children infected with HIV-associated TB died. A further 0.83 million and 0.86 million new cases of TB were reported to be due to alcoholism and smoking, respectively.

TB is a global disease. In 2018, approximately $44 \%$ of new cases occurred in the South-East Asian region, 24\% of new cases were recorded in Africa, and 18\% in the Western Pacific. The most affected countries with high cases of TB include India, Nigeria, Indonesia, Pakistan, Bangladesh, South Africa, and the Philippines. The WHO reported that over 10 million people are affected by TB. One of the health targets for sustainable development goals (SDG) is to end the TB epidemic by 2030, and one of the strategies is to continue searching for nonresistant alternative antimycobacterial agents from natural sources since Mycobacterium tuberculosis has been known to develop resistance to many synthetic drugs.

Most medicinal plants in our environments harbor beneficial fungal endophytes that produce active structural and biological compounds with antimicrobial activity against pathogenic microorganisms [67]. The compounds can be explored in modern medicine [68]. The isolation of fungal endophytes from various medicinal plants with the ability to synthesize new antimycobacterial drugs has been reported [21]. The bioprospecting of fungal endophytes as a remedy to tuberculosis is promising, as many fungal metabolites can easily be explored as antimycobacterials. The isolation of fungal endophytes from Azadirachta indica and Parthenium hysterophorus with antibacterial activity against tuberculosis have been reported [69]. The endophytic fungus, Phomopsis spp. isolated from Garcinia spp. that produces Phomoxanthone A and B has been reported to exhibit antimycobacterial actions against $M$. tuberculosis [51]. The 3-Nitropropionic acid and Tenuazonic acid produced by the fungal endophytes Alternaria alternate and Phomopsis spp., isolated from medicinal plants in Thailand, have reported as exhibiting potent activity against $M$. tuberculosis H37Ra by distorting isocitrate lyase enzyme pathways needed for $M$. tuberculosis metabolism and virulence $[51,70]$. The ability of endophytic fungus Phomopsis spp. isolated from Garcinia adulcis to synthesize the bioactive metabolites Phomoenamide and Phomonitroester has shown inhibitory effects on M. tuberculosis [51]. Chepkirui and Stadler [71] reported inhibition of virulent strains of $M$. tuberculosis by the bioactive compounds of benzopyran, diaportheone A and B synthesized by Diaporthe spp. associated with the leaves of Pandanus amaryllifolius. Furthermore, in vitro studies of the effects of various metabolites secreted from fungal endophytes against the etiological agents of tuberculosis have been reported [72].

\subsection{Antioxidant}

Antioxidants are biological substances that prevent oxidation of chemical compounds. Some food or plant materials are rich in antioxidant content. Antioxidants protect cells from damage by reactive oxygen species (ROS) and free radicals, which cause harmful with pronounced pathological effects such as carcinogenesis, DNA damage, and degenerative diseases like Alzheimer's disease [7]. The exploration of antioxidant components in medicinal plants is promising as an alternative therapy for treating reactive oxygen speciesrelated diseases affecting humans [73,74]. Some of these diseases include hypertension, diabetes, cancer, atherosclerosis, cardiovascular disease, ischemia, arthritis, neurodegenerative diseases, and aging. Several antioxidant compounds from medicinal plants have 
been attributed to antimicrobial, anticancer, antidiabetic, anti-inflammatory, antimutagenic, antiatherosclerotic, anticarcinogenic, and antitumor properties.

Plants and microbes are composed of polysaccharides, and studies have shown the antioxidant properties of polysaccharides obtained from living organisms. The discovery of the antioxidant activity of polysaccharides synthesized by endophytes has been reported [75]. In modern medicine, antioxidants are becoming a promising and alternative natural biological therapy for treating human diseases. The discovery of new antioxidants from plants and microorganisms in combating various diseases has been recognized as a safe and potent chemopreventive therapy for treating reactive oxygen species (ROS) associated with health conditions such as diabetes mellitus, cancer, atherosclerosis, hypertension ischemia/reperfusion injury, cardiovascular disease, rheumatoid arthritis, neurodegenerative diseases, and aging [76]. Some of the natural and new antioxidants include pestacin, corynesidones A and B, 2,14-dihydroxy-7-drimen-12,11-olide, lapachol, coumarin, 5-(hydroxymethyl)-2-furanocarboxylic acid, isopestacin, phloroglucinol, tetrahydroxy-1methylxanthone, salidroside, $p$-tyrosol, borneol, and rutin from fungal endophytes possessing antitumor, anticarcinogenic, antimutagenic or anti-inflammatory properties [77-79]. These compounds with antioxidant properties are effective in the repression of damage from oxygen-derived free radicals and ROS.

Despite research conducted on antioxidants, its clinical trials are still in their infancy as few of them have been approved for clinical use; hence the need for continuing research for a novel and effective antioxidant became imperative. Studies have revealed the bioactivities of metabolites produced from several fungal endophytes. For example, the antioxidant activity of endophytic fungi genera Xylaria spp. and Chaetomium spp. isolated from Nerium oleander and Ginkgo biloba (a common medicinal plant) has been reported [80]. The antioxidants pestacin, isopestacin, graphislactone A produced by endophytic fungi Pestalotiopsis microspore, and Cephalosporin spp. isolated from Terminalia morobensis and Tracheospermum jasminoides have also been reported [78].

\subsection{Antidiabetic}

Diverse natural resources are present and have provided many opportunities in harnessing their potential for medicinal purposes [7]. Diabetes, referred to as Diabetes mellitus, is a disorder in individuals with high blood glucose (blood sugar) due to the lack of insulin production and/or the improper response of the body's cells to insulin [81]. An increase in diabetes cases has become a significant health concern for public health professionals, thus challenging global economy and development.

The research is currently ongoing on exploring effective antidiabetic drugs from natural sources, even from microorganisms. The antidiabetic and antilipidemic activity of fungal endophytes have been reported [82]. The identification of antidiabetic peptides from the endophytic fungi Aspergillus awamori isolated from the medicinal plant Acacia nilotica using high-performance liquid chromatography (HPLC) are well documented [83].

Due to the side effects of some antidiabetic drugs (alpha-glucosidase inhibitor and acarbose), there is a need to search for new and alternative therapies with fewer or no harmful side effects. Fungal endophytes stand as a promising source of natural bioactive metabolites with strong antidiabetic activity and have been considered viable and economical [60]. In vivo and in vitro assays of compound lectin (N-acetylgalactosamine, $64 \mathrm{kDa}$ ) produced by the endophytic fungus Alternaria spp. isolated from Viscum album with healthy antidiabetic activity in the diabetic rat are known [84]. The nonpeptidal metabolite demethylasterriquinone B-1 $(\mathrm{L}-783,281)$ possessing insulinlike activity produced by endophytic fungus Pseudomassaria spp. isolated from African rainforest has also been reported [5].

The antidiabetic potential of endophytic fungal endophytes has indicated their possibility as a source of antidiabetic compounds. The reduction in the fasting blood sugar of experimented diabetic mice administered with purified compounds such as (S)-(+)-2-cis-4trans-abscisic acid, 7'-hydroxy-abscisic acid, and 4-des-hydroxyl altersolanol A from an 
endophytic fungus Nigrospora oryzae associated with the leaves of Combretum dolichopetalum has been reported [85]. Indrianingsih and Tachibana [86] also reported strong $\alpha$-glucosidase inhibitory activity on 8-hydroxy-6,7-dimethoxy-3-methyl isocoumarins, a chemical compound produced by an endophytic fungus, Xylariaceae spp., from the stem of Quercus gilva Blume.

The antidiabetic and hypolipidemic activity extracts from Phoma spp. and Aspergillus spp. isolated from Salvadora oleoides in Wistar albino rats when orally administered glucose and alloxan have been reported to reduce blood sugar levels in rats [87]. The assessment of endophytic fungi from two prominent medicinal plants Rauwolfia densiflora and Leucas ciliate, with antidiabetic bioprospecting for treating diabetes is known $[7,88]$. The authors further reported that the $\alpha$-amylase inhibitor significantly reduces glucose from the complex carbohydrates and slows down the absorption rate of glucose. The screening of endophytic fungi as a precursor for alpha-glucosidase inhibitors has been reported [89]. The antidiabetic activity of compounds produced from Fusarium spp. and Alternaria spp., as a precursor to alpha-glucosidase inhibitors, has been reported in the literature [7], thus, establishing the multifunctional prospect of some fungal endophytes as a source of pharmaceuticals.

\subsection{Antiparasitic and Antimalarial}

Parasitism is a form of symbiotic association that occurs between organisms with one benefiting and other being harmed. A parasite is referred to as an organism that feeds in/on the host and causes damage. Parasites live in/on the host cell [90]. Different microorganisms exist parasitically. Protozoans or helminths are grouped as pathogenic parasites, and their presence in the host plant induced harmful effects. The etiological agent of malaria is Plasmodium species. The common Plasmodium spp. include Plasmodium vivax, P. malariae, P. ovale, and P. falciparum. Globally, the transmission of this protozoan among individuals has caused more than 3.3 billion deaths [7,42]. In 2016, approximately 228 million new malaria cases with more than 405,000 deaths were reported in 91 countries. Malaria is prevalent among individuals in the tropical and Sub-tropical regions of the world; people living in sub-Saharan Africa and Southeast Asia were most affected, with more than $80 \%$ cases caused by Plasmodium falciparum [90]. This parasite affects approximately $45 \%$ of the world's population, especially in developing countries, due to inadequate or insufficient health facilities. Recent reports on drug resistance by malaria parasites have led to an urgent need for alternatives and effective antimalarial drugs with endophytic fungi as promising bioprospecting candidates. Therefore, there is a need to explore bioactive metabolites possessing antimalarial features.

Fungal endophytes have great potential in the synthesis of new antimalarial drugs in the pharmaceutical industry. The synthesis of bioactive metabolite phomoxanthones A-C, an aromatic sesquiterpene, by Phomopsis archeri isolated from Vanilla albindia with remarkable antimalarial properties has been reported [91]. The protozoan genera Trypanosoma and Leishmania are examples of pathogenic parasites. Wang, et al. [92] reported the inhibition of the growth of Leishmania by the bioactive compound Cochlioquonone A produced by Cochliobolus spp. isolated from Piptadonia adiantiodes. The Cercosporin synthesized by Mycosphaerella spp. from Psychotoria horizontalis has also been effectively employed as an antiparasitic agent against Trypanosoma cruzi, Plasmodium falciparum and Leishmania donovani [92].

The antiplasmodial activity of some endophytic fungi producing certain metabolites against Plasmodium falciparum has been reported [93,94]. The antimalarial activity of the endophytic fungus Diaporthe miriciae producing the bioactive metabolite epoxycytochalasin $\mathrm{H}$ against Plasmodium falciparum-resistant strains to antibiotics (chloroquine) has been reported [95]. The in vitro antiplasmodial activity and phytotoxicity of 19,20epoxycytochalasins C and D, cytochalasins and 18-deoxy-19,20-epoxy-cytochalasin C, produced by Nemania spp. UM10M isolated from the leaf of diseased Torreya taxifolia has been reported [96]. Similarly, the research performed by Ateba et al. [42] on the potent 
antiplasmodial extracts from endophytic fungi isolated from Symphonia globulifera against an antibiotic chloroquine-resistant strain Plasmodium falciparum (PfINDO) revealed the potential of isolated endophytic fungi as curative agents for treating malaria. Toghueo, et al. [97] also reported the antiplasmodial activity of Aspergillus versicolor AMb7, Trichoderma afroharziamun AMrb7, Neocosmospora rubicola AMb22, Penicillium citrillium AMrb11, P. citrillium AMrb23, and Fusarium spp. AMst1 against P. falciparum strain.

\subsection{Antiviral}

To find a lasting solution to antibiotic resistance tendencies in microorganisms, developing new antiviral drugs is required with utmost urgency. The bioactive metabolites from endophytic fungi stand a chance as suitable candidates for the synthesis of antiviral agents, thus making this a fascinating area of study. The bioprospecting of endophytic fungi for the synthesis of antiviral agents is promising, although little information has been documented on their exploration. The major constraints encountered in the discovery of antiviral compounds are attributed to inefficient and inappropriate or absent antiviral screening measures in most metabolite compound discovery programs. However, antiviral agents, including cyclosporine U, cytonic acid A, and B, S39163/F-I, podophyllotoxin, sequoiatones C-F, and CR377 have been reported from some fungal endophytes [5].

Antiviral compounds from endophytic fungi possessing strong activity against some viruses, which include human immunodeficiency virus (HIV) [98], human cytomegalovirus, Dengue virus [99], and influenza A (HINI) virus [100] have been reported. The antiviral properties of two new compounds, cytonic acid $\mathrm{A}\left(\mathrm{C}_{32} \mathrm{H}_{36} \mathrm{O}_{10}\right)$ and $\mathrm{B}\left(\mathrm{C}_{32} \mathrm{H}_{36} \mathrm{O}_{10}\right)$ isolated from Cytonaema spp. have been reported [51]. The structural elucidation of $\mathrm{p}$ trideside isomers by mass spectrometry and NMR methods has revealed novel human cytomegalovirus protease inhibitors. The antiviral compound Hinnuliquinone produced by fungal endophytes colonizing the plyllosphere (leaves) part of an oak tree (Quercus coccifera) has been attributed as inhibitor against HIV-1 protease $[51,68]$. The pullularins A-D (cyclo hexadepsi-peptides) produced by Pullularia spp. BCC 8613 were found to exhibit antimalarial activities against $P$. falciparum and antiviral activities against herpes simplex virus (HSV) [51]. The anti-HIV properties of the antiviral compound Pestalotheol$\mathrm{C}$ produced by Pestalotiopsis theae from an unidentified tree on Jianfeng Mountain, China have been reported [51].

The endophytic fungus Alternaria tenuissima QUE1Se produces Altertoxins, an effective compound against HIV-1 virus. Several compounds produced from Emericella spp. (HKZJ), which include emerimidine (A, B), dehydroaustin, austinol, include aspernidine (A, B), Austin, emeriphenolicins (A, D) and acetoxy dehydroaustin have been reported to exhibit antiviral activity against influenza A virus (H1N1) [99]. The crude extract from most medicinal plants has displayed a high degree of antiviral activity. Besides the fungal endophytes found in the plants, some groups of actinomycetes have been reported to display antiviral activities [7]. For example, Streptomyces spp. GT2002/1503 has been reported to exhibit antiviral actions against R5 tropic HIV infection [100]. The antiviral compound 2-(furan-2-yl)-6-(2S, 3S, 4-trihydroxybutyl) pyrazine produced from Jishengella endophytica 161111 with antiviral activity against influenza A virus (subtype H1N1) has been reported [7].

\subsection{Immunosuppressive}

The roles of fungal endophytes are known in agriculture and in the pharmaceutical industry [101]. Nowadays, the search for endophytic resources in clinical medicine is ongoing as a source of immunomodulatory compounds with a prospect for treating autoimmune disorders such as insulin-dependent diabetes and rheumatoid arthritis and precursors that avert allograft declination in transplant patients [102]. Fungal endophytes are capable of synthesizing certain compounds with immunosuppressive action [103]. Due to the heterogeneous mechanisms of most of the synthetic (chemical) immunosuppressive drugs, their effects are consequentially challenging due to their prolonged use for 
treating diseases. The side effects of the continuous use of chemical immunosuppressive drugs include hyperlipidemia, nephrotoxicity, hypertension, neurotoxicity, and the risk of infection [104].

The continuous intervention in the search for effective and friendly immunosuppressive drugs is currently ongoing and recent research findings have discovered potent immunosuppressive therapies from fungal endophytes including sydoxanthone A and B, colutellin A, 13-O-acetylsydowinin B, dibenzofurane, methyl peniphenone, xanthone derivatives, subglutinol A and B, lipopeptide, peniphenone, benzophenone derivatives, $(-)$ mycousnine, polyketide benzannulated spiroketal, and polyketide benzannulated spiroketal [105].

The isolation of the immunosuppressant drug Cyclosporin A from Tolypocladium inflatum has been reported [106]. The finding of cyclosporin A extracted from the soil endophytic fungus Trichoderma polysporum as a principal immunosuppressive agent is also known. Diterpene pyrenes, a noncytotoxic compound, and Subglutinol A and B produced by fungal endophytes Fusarium subglutinan isolated from Tripterygium wilfordii with immunosuppressive action have also been reported [107]. The inclusion of Subglutinol A and $\mathrm{B}$ in an equal amounts of $0.1 \mu \mathrm{M}$ to mixed lymphocyte reaction assay and thymocyte proliferation assay yielded an equal percentage (50\%) inhibitory concentration [108]. Similarly, the commercial immunosuppressant drug cyclosporine used in the same assay systems has shown inhibition in the mixed lymphocyte reaction assay and $10^{4}$ more in the thymocyte proliferation assay. Nevertheless, the shortfall in the toxicity associated with subglutinols A and B necessitates possible exploration in further studies. The cyclosporine produced by Tolypocladium inflatum can be a potential candidate for large exploration of immunosuppressants. The example given by the authors has depicted the progression of many scientists in the search for unknown or unidentified endophytes from fascinating and uncommon hosts and environments.

The synthesis of mycophenolic acid from endophytic fungi in the genera Busssochlamys, Penicillium, Septoria, and Aspergillus has been reported [109]. Mycophenolic acid is a potent immunosuppressant used in medicine for treating autoimmune diseases, thus preventing rejection reaction in a transplanted organ. The in vivo and in vitro studies conducted by Lin, et al. [110] reported the effectiveness of subglutinol A causing blockages in the T-lymphocytes' (T-cell) growth and survival. The inhibition of colutellin $\mathrm{A}$ on $\mathrm{CD}_{4}$ (cluster differences 4 ) - T cell activation of IL-2 (Interleukin 2) produced with an $\mathrm{IC}_{50}$ (half maximal inhibitory concentration) of 167.3/0.38 nM with nontoxicity on human peripheral blood mononuclear cells has been reported [111]. The potential of natural bioactive compounds subglutinol A and colutellin A produced from endophytic fungi can be used as alternative immunosuppressive drugs for treating autoimmune diseases. However, the identification of actual molecular specificity and explicit mechanisms of action of these drugs is unknown. The novel compounds from fungal endophytes can accomplish the recent demand for new and affordable immunosuppressive therapeutic drugs that can be explored as medicaments to autoimmune diseases and posttransplantation care.

\section{Conclusions and Future Outlook}

Research into the microbial world of plants is currently fascinating with great promise in agriculture, pharmaceuticals and medicine. The efficacy of medicinal plants and associated endophytes has gained attention from scientists in the assessment of their pharmacological potential in the synthesis of the bioactive compounds naturally present in them. Medicinal plants contain many phytochemical constituents that can be explored as medicaments to human diseases.

Currently, the outlook of medicinal compounds and high demand for nontoxic drugs have diversified in the search for novel biologically active metabolites from plant endophytes. Although the exploration of bioactive compounds and the use of some medicinal plants such as sunflower in traditional medicine has long been studied, little information is available on the bioactivities of its associated fungal endophytes. Furthermore, the research 
into various pharmacological effects of bioactive compounds from endophytes is still in infancy. Nevertheless, review documentation on their functions can provide insights into possible explorations, as outlined in this review work.

Thus, the screening of fungal endophytes for possible bioactive metabolite synthesis can help in the establishment of their pharmacological functions as well as for research in providing information on the bioprospecting of endophytic fungi as biological entities that will ensure sustainable human health and action against antibiotic resistance.

Author Contributions: Both authors contributed equally. Both authors have read and agreed to the published version of the manuscript.

Funding: This study was funded by the National Research Foundation of South Africa (UID: 123634).

Acknowledgments: B.S.A. is grateful to the National Research Foundation (NRF), South Africa/The World Academy of Science African Renaissance Ph.D. scholarship (Ref: UID: 116100). O.O.B. acknowledges NRF for the grant (UID: 123634) that supports research in her laboratory.

Conflicts of Interest: The authors declare that there is no conflict of interest.

\section{References}

1. Kraupner, N.; Ebmeyer, S.; Bengtsson-Palme, J.; Fick, J.; Kristiansson, E.; Flach, C.-F.; Larsson, D.J. Selective concentration for ciprofloxacin resistance in Escherichia coli grown in complex aquatic bacterial biofilms. Environ. Int. 2018, 116, 255-268. [CrossRef]

2. Bengtsson-Palme, J.; Kristiansson, E.; Larsson, D.J. Environmental factors influencing the development and spread of antibiotic resistance. FEMS Microbiol. Rev. 2018, 42, 68-80. [CrossRef] [PubMed]

3. Adeleke, B.S.; Babalola, O.O. The endosphere microbial communities, a great promise in agriculture. Int. Microbiol. 2020. [CrossRef]

4. Stekel, D. First report of antimicrobial resistance pre-dates penicillin. Nature 2018, 562, 192. [CrossRef] [PubMed]

5. Gupta, S.; Chaturvedi, P.; Kulkarni, M.G.; Van Staden, J. A critical review on exploiting the pharmaceutical potential of plant endophytic fungi. Biotechnol. Adv. 2020, 39, 107462. [CrossRef]

6. Akinola, S.A.; Babalola, O.O. The fungal and archaeal community within plant rhizosphere: A review on their contribution to crop safety. J. Plant. Nutr. 2021, 44, 600-618. [CrossRef]

7. Fadiji, A.E.; Babalola, O.O. Elucidating mechanisms of endophytes used in plant protection and other bioactivities with multifunctional prospects. Front. Bioeng. Biotechnol. 2020, 8, 467. [CrossRef]

8. Fadiji, A.E.; Ayangbenro, A.S.; Babalola, O.O. Organic farming enhances the diversity and community structure of endophytic archaea and fungi in maize plant: A shotgun approach. J. Soil Sci. Plant. Nutr. 2020, 20, 2587-2599. [CrossRef]

9. Omomowo, O.I.; Babalola, O.O. Bacterial and fungal endophytes: Tiny giants with immense beneficial potential for plant growth and sustainable agricultural productivity. Microorganisms 2019, 7, 481. [CrossRef]

10. Hiruma, K.; Kobae, Y.; Toju, H. Beneficial associations between Brassicaceae plants and fungal endophytes under nutrient-limiting conditions: Evolutionary origins and host-symbiont molecular mechanisms. Curr. Opin. Plant Biol. 2018, 44, 145-154. [CrossRef] [PubMed]

11. Igiehon, N.O.; Babalola, O.O.; Cheseto, X.; Torto, B. Effects of rhizobia and arbuscular mycorrhizal fungi on yield, size distribution and fatty acid of soybean seeds grown under drought stress. Microbiol. Res. 2021, 242, 126640. [CrossRef]

12. Emmanuel, O.C.; Babalola, O.O. Productivity and quality of horticultural crops through co-inoculation of arbuscular mycorrhizal fungi and plant growth promoting bacteria. Microbiol. Res. 2020, 239, 126569. [CrossRef]

13. Odelade, K.A.; Babalola, O.O. Bacteria, fungi and archaea domains in rhizospheric soil and their effects in enhancing agricultural productivity. Int. J. Environ. Res. Public Health 2019, 16, 3873. [CrossRef]

14. Wu, B.; Hussain, M.; Zhang, W.; Stadler, M.; Liu, X.; Xiang, M. Current insights into fungal species diversity and perspective on naming the environmental DNA sequences of fungi. Mycology 2019, 10, 127-140. [CrossRef] [PubMed]

15. Hawksworth, D.L.; Lücking, R. Fungal diversity revisited: 2.2 to 3.8 million species. Fungal Kingd. 2017, 5, 79-95.

16. Palanichamy, P.; Krishnamoorthy, G.; Kannan, S.; Marudhamuthu, M. Bioactive potential of secondary metabolites derived from medicinal plant endophytes. Egypt. J. Basic Appl. Sci. 2018, 5, 303-312. [CrossRef]

17. Manganyi, M.; Regnier, T.; Kumar, A.; Bezuidenhout, C.; Ateba, C. Biodiversity and antibacterial screening of endophytic fungi isolated from Pelargonium sidoides. South Afr. J. Bot. 2018, 116, 192-199. [CrossRef]

18. Manganyi, M.C.; Tchatchouang, C.-D.K.; Regnier, T.; Bezuidenhout, C.C.; Ateba, C.N. Bioactive compound produced by endophytic fungi isolated from Pelargonium sidoides against selected bacteria of clinical importance. Mycobiology 2019, 47, 335-339. [CrossRef] [PubMed]

19. Sharma, A.; Kumar, V.; Kanwar, M.; Thukral, A.; Bhardwaj, R. Phytochemical profiling of the leaves of Brassica juncea L. using GC-MS. Int. Food Res. J. 2017, 24, 547.

20. Michel, J.; Abd Rani, N.Z.; Husain, K. A review on the potential use of medicinal plants from Asteraceae and Lamiaceae plant family in cardiovascular diseases. Front. Pharmacol. 2020, 11, 852. [CrossRef] 
21. Nisa, H.; Kamili, A.N.; Nawchoo, I.A.; Shafi, S.; Shameem, N.; Bandh, S.A. Fungal endophytes as prolific source of phytochemicals and other bioactive natural products: A review. Microb. Pathog. 2015, 82, 50-59. [CrossRef] [PubMed]

22. Lu, S.; Qiu, Y.; Ni, D.; He, X.; Pu, J.; Zhang, J. Emergence of allosteric drug-resistance mutations: New challenges for allosteric drug discovery. Drug Discov. Today 2020, 25, 177-184. [CrossRef] [PubMed]

23. Sandargo, B.; Chepkirui, C.; Cheng, T.; Chaverra-Muñoz, L.; Thongbai, B.; Stadler, M.; Hüttel, S. Biological and chemical diversity go hand in hand: Basidiomycota as source of new pharmaceuticals and agrochemicals. Biotechnol. Adv. 2019, 37, 107344. [CrossRef] [PubMed]

24. Chowdhary, K.; Kaushik, N. Fungal endophyte diversity and bioactivity in the Indian medicinal plant Ocimum sanctum Linn. PLoS ONE 2015, 10, e0141444. [CrossRef]

25. Prakash, V.; Rana, S.; Sagar, A. Taxomyces andreanae: A source of anticancer drug. Int. J. Bot. Stud. 2016, 1, 43-46.

26. Naik, B.S. Developments in taxol production through endophytic fungal biotechnology: A review. Orient. Pharm. Exp. Med. 2019, 19, 1-13. [CrossRef]

27. Gómez, O.C.; Luiz, J.H.H. Endophytic fungi isolated from medicinal plants: Future prospects of bioactive natural products from Tabebuia/Handroanthus endophytes. Appl. Microbiol. Biotechnol. 2018, 102, 9105-9119. [CrossRef]

28. Caruso, G.; Abdelhamid, M.T.; Kalisz, A.; Sekara, A. Linking endophytic fungi to medicinal plants therapeutic activity. A case study on asteraceae. Agriculture 2020, 10, 286. [CrossRef]

29. Chathurdevi, G.; Gowrie, S. Endophytic fungi isolated from medical plant-A promising source of potential bioactive metabolites. Int. J. Curr. Pharm. Res. 2016, 8, 50-56.

30. Jia, M.; Chen, L.; Xin, H.-L.; Zheng, C.-J.; Rahman, K.; Han, T.; Qin, L.-P. A friendly relationship between endophytic fungi and medicinal plants: A systematic review. Front. Microbiol. 2016, 7, 906. [CrossRef] [PubMed]

31. Ejaz, M.; Javed, S.; Hamza, M.; Tabassum, S.; Abubakar, M.; Ullah, I. Fungal endophytes are effective alternatives and novel sources of anticancer drugs. Punjab Univ. J. Zool. 2020, 35, 13-24.

32. Baker, S.; Satish, S. Endophytes: Natural warehouse of bioactive compounds. Drug Invent. Today 2012, 4, 548-553.

33. Costa, J.H.; Wassano, C.I.; Angolini, C.F.F.; Scherlach, K.; Hertweck, C.; Fill, T.P. Antifungal potential of secondary metabolites involved in the interaction between citrus pathogens. Sci. Rep. 2019, 9, 18647. [CrossRef] [PubMed]

34. Huang, W.-Y.; Cai, Y.-Z.; Xing, J.; Corke, H.; Sun, M. A potential antioxidant resource: Endophytic fungi from medicinal plants. Econ. Bot. 2007, 61, 14-30. [CrossRef]

35. Hussain, H.; John, M.; Al-Harrasi, A.; Shah, A.; Hassan, Z.; Abbas, G.; Rana, U.A.; Green, I.R.; Schulz, B.; Krohn, K. Phytochemical investigation and antimicrobial activity of an endophytic fungus Phoma spp. J. King Saud. Univ. Sci. 2015, 27, 92-95. [CrossRef]

36. Parthasarathy, R.; Sathiyabama, M. Lovastatin-producing endophytic fungus isolated from a medicinal plant Solanum xanthocarpum. Nat. Prod. Res. 2015, 29, 2282-2286. [CrossRef]

37. Nuraini, F.R.; Setyaningsih, R.; Susilowati, A. Antioxidant activity of bioactive compound produced by endophytic fungi isolated from endemic plant of South Kalimantan Mangifera casturi Kosterm. In Proceedings of the AIP Conference Proceedings, Malang, Indonesia, 13-14 March 2019; p. 080013.

38. Cui, J.-L.; Guo, T.-T.; Ren, Z.-X.; Zhang, N.-S.; Wang, M.-L. Diversity and antioxidant activity of culturable endophytic fungi from alpine plants of Rhodiola crenulata, R. angusta, and R. sachalinensis. PLoS ONE 2015, 10, e0118204. [CrossRef]

39. Khan, A.L.; Gilani, S.A.; Waqas, M.; Al-Hosni, K.; Al-Khiziri, S.; Kim, Y.-H.; Ali, L.; Kang, S.-M.; Asaf, S.; Shahzad, R. Endophytes from medicinal plants and their potential for producing indole acetic acid, improving seed germination and mitigating oxidative stress. J. Zhejiang Univ. Sci. B 2017, 18, 125-137. [CrossRef]

40. Zhou, J.; Diao, X.; Wang, T.; Chen, G.; Lin, Q.; Yang, X.; Xu, J. Phylogenetic diversity and antioxidant activities of culturable fungal endophytes associated with the mangrove species Rhizophora stylosa and R. mucronata in the South China Sea. PLoS ONE 2018, 13, e0197359. [CrossRef]

41. Gill, E.E.; Franco, O.L.; Hancock, R.E. Antibiotic adjuvants: Diverse strategies for controlling drug-resistant pathogens. Chem. Biol. Aand Drug Des. 2015, 85, 56-78. [CrossRef]

42. Ateba, J.E.; Toghueo, R.M.; Awantu, A.F.; Mba'ning, B.M.; Gohlke, S.; Sahal, D.; Rodrigues-Filho, E.; Tsamo, E.; Boyom, F.F.; Sewald, N. Antiplasmodial properties and cytotoxicity of endophytic fungi from Symphonia globulifera (Clusiaceae). J. Fungi 2018, 4, 70. [CrossRef]

43. Gouda, S.; Das, G.; Sen, S.K.; Shin, H.-S.; Patra, J.K. Endophytes: A treasure house of bioactive compounds of medicinal importance. Front. Microbiol. 2016, 7, 1538. [CrossRef] [PubMed]

44. Singh, M.; Kumar, A.; Singh, R.; Pandey, K.D. Endophytic bacteria: A new source of bioactive compounds. Biotechnology 2017, 7, 315. [CrossRef] [PubMed]

45. Rustamova, N.; Bozorov, K.; Efferth, T.; Yili, A. Novel secondary metabolites from endophytic fungi: Synthesis and biological properties. Phytochem. Rev. 2020, 16, 425-448. [CrossRef]

46. Wu, F.; Yang, D.; Zhang, L.; Chen, Y.; Hu, X.; Li, L.; Liang, J. Diversity estimation and antimicrobial activity of culturable endophytic fungi from Litsea cubeba (Lour.) Pers. in China. Forests 2019, 10, 33. [CrossRef]

47. Mogana, R.; Adhikari, A.; Tzar, M.; Ramliza, R.; Wiart, C. Antibacterial activities of the extracts, fractions and isolated compounds from Canarium patentinervium Miq. against bacterial clinical isolates. BMC Complementary Med. Ther. 2020, 20, 55. [CrossRef] [PubMed] 
48. Ghorbanpour, M.; Omidvari, M.; Abbaszadeh-Dahaji, P.; Omidvar, R.; Kariman, K. Mechanisms underlying the protective effects of beneficial fungi against plant diseases. Biol. Control. 2018, 117, 147-157. [CrossRef]

49. Alborés, S.; Sanguinedo, P.; Held, B.H.; Cerdeiras, M.P.; Blanchette, R.A. Biodiversity and antimicrobial activity of Antarctic fungi from the Fildes Peninsula, King George Island. Sydowia 2018, 70, 185-191.

50. Pisoschi, A.M.; Pop, A.; Georgescu, C.; Turcuş, V.; Olah, N.K.; Mathe, E. An overview of natural antimicrobials role in food. Eur. J. Med. Chem. 2018, 143, 922-935. [CrossRef]

51. Kumar, G.; Chandra, P.; Choudhary, M. Endophytic fungi: A potential source of bioactive compounds. Chem. Sci. Rev. Lett. 2017, 6, 2373-2381.

52. Yazgan, H.; Ozogul, Y.; Kuley, E. Antimicrobial influence of nanoemulsified lemon essential oil and pure lemon essential oil on food-borne pathogens and fish spoilage bacteria. Int. J. Food Microbiol. 2019, 306, 108266. [CrossRef]

53. Macías-Rubalcava, M.L.; Sánchez-Fernández, R.E. Secondary metabolites of endophytic Xylaria species with potential applications in medicine and agriculture. World J. Microbiol. Biotechnol. 2017, 33, 15. [CrossRef] [PubMed]

54. Reshma, J.; Vinaya, C.; Linu, M. Agricultural applications of endophytic microflora. In Seed Endophytes; Springer: Berlin/Heidelberg, Germany, 2019; pp. 385-403.

55. Pan, D.; Mionetto, A.; Tiscornia, S.; Bettucci, L. Endophytic bacteria from wheat grain as biocontrol agents of Fusarium graminearum and deoxynivalenol production in wheat. Mycotoxin Res. 2015, 31, 137-143. [CrossRef]

56. Huang, S.; Xu, J.; Li, F.; Zhou, D.; Xu, L.; Li, C. Identification and antifungal activity of metabolites from the mangrove fungus Phoma sp. L28. Chem. Nat. Compd. 2017, 53, 237-240. [CrossRef]

57. Kumar, V.; Soni, R.; Jain, L.; Dash, B.; Goel, R. Endophytic fungi: Recent advances in identification and explorations. In Advances in Endophytic Fungal Research; Springer: Berlin/Heidelberg, Germany, 2019; pp. 267-281.

58. Puri, S.K.; Habbu, P.V.; Kulkarni, P.V.; Kulkarni, V.H. Nitrogen containing secondary metabolites from endophytes of medicinal plants and their biological/pharmacological activities-A review. Syst. Rev. Pharm. 2018, 9, 22-30. [CrossRef]

59. Kamana, S.; Hemalatha, K.; Chandanavineela, K.; Kalyani, P.; Hemalatha, V. Endophytic fungi: As source of bioactive compound. World J. Pharmacol. Pharm. Sci. 2016, 5, 1026-1040.

60. Kouipou Toghueo, R.M.; Boyom, F.F. Endophytic fungi from Terminalia species: A comprehensive review. J. Fungi 2019, 5, 43. [CrossRef] [PubMed]

61. Fill, T.P.; Silva, B.F.D.; Rodrigues-Fo, E. Biosynthesis of phenylpropanoid amides by an endophytic Penicillium brasilianum found in root bark of Melia azedarach. J. Microbiol. Biotechnol. 2010, 20, 622-629.

62. Ardalani, H.; Avan, A.; Ghayour-Mobarhan, M. Podophyllotoxin: A novel potential natural anticancer agent. Avicenna J. Phytomed. 2017, 7, 285.

63. Chen, L.; Zhang, Q.-Y.; Jia, M.; Ming, Q.-L.; Yue, W.; Rahman, K.; Qin, L.-P.; Han, T. Endophytic fungi with antitumor activities: Their occurrence and anticancer compounds. Crit. Rev. Microbiol. 2016, 42, 454-473. [CrossRef]

64. Li, S.-J.; Zhang, X.; Wang, X.-H.; Zhao, C.-Q. Novel natural compounds from endophytic fungi with anticancer activity. Eur. J. Med. Chem. 2018, 156, 316-343. [CrossRef]

65. Kharwar, R.N.; Mishra, A.; Gond, S.K.; Stierle, A.; Stierle, D. Anticancer compounds derived from fungal endophytes: Their importance and future challenges. Nat. Prod. Rep. 2011, 28, 1208-1228. [CrossRef]

66. Siroka, A.; Ponce, N.A.; Lönnroth, K. Association between spending on social protection and tuberculosis burden: A global analysis. Lancet Infect. Dis. 2016, 16, 473-479. [CrossRef]

67. Egbuta, M.A.; Mwanza, M.; Babalola, O.O. A review of the ubiquity of ascomycete's filamentous fungi in relation to their economic and medical importance. Adv. Microbiol. 2016, 6, 1140-1158. [CrossRef]

68. Uzma, F.; Mohan, C.D.; Hashem, A.; Konappa, N.M.; Rangappa, S.; Kamath, P.V.; Singh, B.P.; Mudili, V.; Gupta, V.K.; Siddaiah, C.N. Endophytic fungi-Alternative sources of cytotoxic compounds: A review. Front. Pharmacol. 2018, 9, 309. [CrossRef] [PubMed]

69. Mane, R.; Shinde, M.; Wagh, P.; Malkar, H. Isolation of endophytic microorganisms as a source of novel secondary metabolite producers against tuberculosis. Int. J. Sci. Res. Technol. 2017, 3, 1267-1269.

70. Deshmukh, S.K.; Verekar, S.A.; Bhave, S.V. Endophytic fungi: A reservoir of antibacterials. Front. Microbiol. 2015, 5, 715. [CrossRef]

71. Chepkirui, C.; Stadler, M. The genus Diaporthe: A rich source of diverse and bioactive metabolites. Mycol. Prog. 2017, 16, 477-494. [CrossRef]

72. Silva, E.M.S.; Silva, I.R.d.; Ogusku, M.M.; Carvalho, C.M.; Maki, C.S.; Procópio, R.E.D.L. Metabolites from endophytic Aspergillus fumigatus and their in vitro effect against the causal agent of tuberculosis. Acta Amaz. 2018, 48, 63-69. [CrossRef]

73. Khiralla, A.; Mohamed, I.; Thomas, J.; Mignard, B.; Spina, R.; Yagi, S.; Laurain-Mattar, D. A pilot study of antioxidant potential of endophytic fungi from some Sudanese medicinal plants. Asian Pac. J. Trop. Med. 2015, 8, 701-704. [CrossRef]

74. Ambele, C.F.; Bisseleua, H.D.; Akutse, K.S.; Babalola, O.O.; Humbert, P.; Patel, A.; Vidal, S.; Djuideu, C.T.; Ekesi, S. Testing a co-formulation of $\mathrm{CO}_{2}$-releasing material with an entomopathogenic fungus for the management of subterranean termite pests. Mycol. Prog. 2019, 18, 1201-1211. [CrossRef]

75. Ma, J.-S.; Liu, H.; Han, C.-R.; Zeng, S.-J.; Xu, X.-J.; Lu, D.-J.; He, H.-J. Extraction, characterization and antioxidant activity of polysaccharide from Pouteria campechiana seed. Carbohydr. Polym. 2020, 229, 115409. [CrossRef]

76. Sujatha, J.; Asokan, S. Antidermatophytic and antioxidant activity of hexane extracts of Cassia alata leaves and its phytochemical screening. Int. Res. J. Pharm. Biosci. 2017, 4, 25-35. 
77. Toghueo, R.M.K. Bioprospecting endophytic fungi from Fusarium genus as sources of bioactive metabolites. Mycology 2020, 11, 1-21. [CrossRef]

78. Toghueo, R.M.K.; Boyom, F.F. Endophytes from ethno-pharmacological plants: Sources of novel antioxidants-A systematic review. Biocatal. Agric. Biotechnol. 2019, 22, 101430. [CrossRef]

79. Khiralla, A.; Spina, R.; Saliba, S.; Laurain-Mattar, D. Diversity of natural products of the genera Curvularia and Bipolaris. Fungal Biol. Rev. 2019, 33, 101-122. [CrossRef]

80. Gunasekaran, S.; Sundaramoorthy, S.; Anitha, U.; Sathiavelu, M.; Arunachalam, S. Endophytic fungi with antioxidant activity-A review. Res. J. Pharm. Technol. 2015, 8, 731-737. [CrossRef]

81. Ushasri, R.; Anusha, R. In vitro anti-diabetic activity of ethanolic and acetone extracts of endophytic fungi Syncephalastrum racemosum isolated from the seaweed Gracilaria corticata by alpha-amylase inhibition assay method. Int. J. Curr. Microbiol. Appl. Sci. 2015, 4, 254-259.

82. Rathnayake, G.N.; Kumar, N.S.; Jayasinghe, L.; Araya, H.; Fujimoto, Y. Secondary metabolites produced by an endophytic fungus Pestalotiopsis microspora. Nat. Prod. Bioprospecting 2019, 9, 411-417. [CrossRef]

83. Singh, B.; Kaur, A. Antidiabetic potential of a peptide isolated from an endophytic Aspergillus awamori. J. Appl. Microbiol. 2016, 120, 301-311. [CrossRef]

84. Govindappa, M. A review on role of plant(s) extracts and its phytochemicals for the management of diabetes. J. Diabetes Metab. 2015, 6, 1-38.

85. Uzor, P.F.; Osadebe, P.O.; Nwodo, N.J. Antidiabetic activity of extract and compounds from an endophytic fungus Nigrospora oryzae. Drug Res. 2017, 67, 308-311. [CrossRef] [PubMed]

86. Indrianingsih, A.W.; Tachibana, S. $\alpha$-Glucosidase inhibitor produced by an endophytic fungus, Xylariaceae sp. QGS 01 from Quercus gilva Blume. Food Sci. Hum. Wellness 2017, 6, 88-95. [CrossRef]

87. Ezekwesili, C.N.; Ogbunugafor, H.A. Blood glucose lowering activity of five Nigerian medicinal plants in alloxan-induced diabetic Wistar albino rats. Anim. Res. Int. 2015, 12, 2150-2158.

88. Akshatha, V.; Nalini, M.; D'souza, C.; Prakash, H. Streptomycete endophytes from anti-diabetic medicinal plants of the Western Ghats inhibit alpha-amylase and promote glucose uptake. Lett. Appl. Microbiol. 2014, 58, 433-439. [CrossRef] [PubMed]

89. Kaur, J.; Kaur, R.; Datta, R.; Kaur, S.; Kaur, A. Exploration of insecticidal potential of an alpha glucosidase enzyme inhibitor from an endophytic Exophiala spinifera. J. Appl. Microbiol. 2018, 125, 1455-1465. [CrossRef]

90. Muhammed, D.; Dada, E.; Iyaji, F.; Abraham, O.; Chijioke, N. Investigation of biochemical parameters of Plasmodium berghei infected mice after administration of ethanolic leaf extract of Eucalyptus citriodora. Int. J. Pathog. Res. 2019, 2, 1-9. [CrossRef]

91. Aharwal, R.P.; Kumar, S.; Sandhu, S.S. Endophytic mycoflora as a source of biotherapeutic compounds for disease treatment. J. Appl. Pharm. Sci. 2016, 6, 242-254. [CrossRef]

92. Wang, L.-W.; Wang, J.-L.; Chen, J.; Chen, J.-J.; Shen, J.-W.; Feng, X.-X.; Kubicek, C.P.; Lin, F.-C.; Zhang, C.-L.; Chen, F.-Y. A novel derivative of (-) mycousnine produced by the endophytic fungus Mycosphaerella nawae, exhibits high and selective immunosuppressive activity on T cells. Front. Microbiol. 2017, 8, 1251. [CrossRef]

93. Yang, B.; Huang, J.; Zhou, X.; Lin, X.; Liu, J.; Liao, S.; Wang, J.; Liu, F.-A.; Tao, H.; Liu, Y. The fungal metabolites with potential antiplasmodial activity. Curr. Med. Chem. 2018, 25, 3796-3825. [CrossRef]

94. Purwantini, I.; Wahyono, M.; Susidarti, R.A.; Sholikhah, E.N.; Rani, A. Antiplasmodial activity of endophytic fungi isolated from Artemisia Annua, L. Int. J. Pharm. Clin. Res. 2016, 8, 341-344.

95. Ferreira, M.C.; Cantrell, C.L.; Wedge, D.E.; Gonçalves, V.N.; Jacob, M.R.; Khan, S.; Rosa, C.A.; Rosa, L.H. Antimycobacterial and antimalarial activities of endophytic fungi associated with the ancient and narrowly endemic neotropical plant Vellozia gigantea from Brazil. Mem. Inst. Oswaldo Cruz 2017, 112, 692-697. [CrossRef]

96. Kumarihamy, M.; Ferreira, D.; Croom, E.M.; Sahu, R.; Tekwani, B.L.; Duke, S.O.; Khan, S.; Techen, N.; Nanayakkara, N. Antiplasmodial and cytotoxic cytochalasins from an endophytic fungus, Nemania sp. UM10M, isolated from a diseased Torreya taxifolia leaf. Molecules 2019, 24, 777. [CrossRef]

97. Toghueo, R.M.K.; Kemgne, E.A.M.; Eke, P.; Kanko, M.I.M.; Dize, D.; Sahal, D.; Boyom, F.F. Antiplasmodial potential and GC-MS fingerprint of endophytic fungal extracts derived from Cameroonian Annona muricata. J. Ethnopharmacol. 2019, 235, 111-121. [CrossRef]

98. Farooq, T.; Hameed, A.; Rehman, K.; Ibrahim, M.; Qadir, M.I.; Akash, M.S.H. Antiretroviral agents: Looking for the best possible chemotherapeutic options to conquer HIV. Crit. Rev. Eukaryot. Gene Expr. 2016, 26, 363-381. [CrossRef]

99. Raekiansyah, M.; Mori, M.; Nonaka, K.; Agoh, M.; Shiomi, K.; Matsumoto, A.; Morita, K. Identification of novel antiviral of fungus-derived brefeldin A against dengue viruses. Trop. Med. Health 2017, 45, 32. [CrossRef]

100. Liu, S.-S.; Jiang, J.-X.; Huang, R.; Wang, Y.-T.; Jiang, B.-G.; Zheng, K.-X.; Wu, S.-H. A new antiviral 14-nordrimane sesquiterpenoid from an endophytic fungus Phoma spp. Phytochem. Lett. 2019, 29, 75-78. [CrossRef]

101. Ambele, C.F.; Ekesi, S.; Bisseleua, H.D.; Babalola, O.O.; Khamis, F.M.; Djuideu, C.T.; Akutse, K.S. Entomopathogenic fungi as endophytes for biological control of subterranean termite pests attacking cocoa seedlings. J. Fungi 2020, 6, 126. [CrossRef]

102. Kim, E.Y.; Moudgil, K.D. Immunomodulation of autoimmune arthritis by pro-inflammatory cytokines. Cytokine 2017, $98,87-96$. [CrossRef] [PubMed]

103. Egbuta, M.A.; Mwanza, M.; Babalola, O.O. Health risks associated with exposure to filamentous fungi. Int. J. Environ. Res. Public Health 2017, 14, 719. [CrossRef] [PubMed] 
104. Hošková, L.; Málek, I.; Kopkan, L.; Kautzner, J. Pathophysiological mechanisms of calcineurin inhibitor-induced nephrotoxicity and arterial hypertension. Physiol. Res. 2017, 66, 167. [CrossRef] [PubMed]

105. Leroy, C.; Rigot, J.-M.; Leroy, M.; Decanter, C.; Le Mapihan, K.; Parent, A.-S.; Le Guillou, A.-C.; Yakoub-Agha, I.; Dharancy, S.; Noel, C. Immunosuppressive drugs and fertility. Orphanet J. Rare Dis. 2015, 10, 136. [CrossRef] [PubMed]

106. El-Gowelli, H.M.; El-Mas, M.M. Central modulation of cyclosporine-induced hypertension. Naunyn-Schmiedeberg's Arch. Pharmacol. 2015, 388, 351-361. [CrossRef]

107. Vasundhara, M.; Baranwal, M.; Kumar, A. Fusarium tricinctum, an endophytic fungus exhibits cell growth inhibition and antioxidant activity. Indian J. Microbiol. 2016, 56, 433-438. [CrossRef] [PubMed]

108. Nalini, M.; Prakash, H. Diversity and bioprospecting of actinomycete endophytes from the medicinal plants. Lett. Appl. Microbiol. 2017, 64, 261-270. [CrossRef]

109. Song, X.; Tu, R.; Mei, X.; Wu, S.; Lan, B.; Zhang, L.; Luo, X.; Liu, J.; Luo, M. A mycophenolic acid derivative from the fungus Penicillium sp. SCSIO sof101. Nat. Prod. Res. 2020, 34, 1206-1212. [CrossRef]

110. Lin, R.; Kim, H.; Hong, J.; Li, Q.-J. Biological evaluation of subglutinol A as a novel immunosuppressive agent for inflammation intervention. ACS Med. Chem. Lett. 2014, 5, 485-490. [CrossRef]

111. Strobel, G. The emergence of endophytic microbes and their biological promise. J. Fungi 2018, 4, 57. [CrossRef] 